\title{
ENTRUSTING COAST GUARDS WITH MARITIME LAW ENFORCEMENT POWERS: LESSONS FOR MALAYSIA
}

\author{
Abdul Ghafur Hamid @ Khin Maung Sein* \\ Maizatun Mustafa** \\ Su Wai Mon**
}

\begin{abstract}
In view of many and varied maritime threats and the growing number of maritime crimes, it is necessary for States to have coast guards with maritime law enforcement powers to secure their maritime territories and protect maritime interests. Modern coast guards play a crucial role in sustaining maritime security and their operations have become more and more sophisticated. However, in the case of the Malaysian Maritime Enforcement Agency (MMEA), commonly known as the Malaysian Coast Guard, it is found that it is still struggling even after twelve years of its establishment to achieve its primary objective of becoming a single maritime law enforcement agency in Malaysia. The present study finds that there seems to be a veiled competition between the MMEA on one side, and the other law enforcement bodies on the other. An analysis of the practice of coast guards of the USA, India and Japan is made to find a solution to this crucial issue revolving around Malaysia's maritime security. The study finally concludes that the controversial section 7(3) of the MMEA Act should be amended to clearly entrust the MMEA with, and exclude other relevant agencies from, maritime law enforcement powers in the Malaysian maritime zones.
\end{abstract}

Keywords: Maritime security, maritime law enforcement, coast guards, MMEA, marine police

* Professor and Coordinator of International Law and Maritime Affairs (ILMA) Research Unit, Ahmad Ibrahim Kulliyyah of Laws, International Islamic University Malaysia. This paper is part of the research findings of the Research Project entitled "Formulation of a Legal Framework for Sustaining Maritime Security in Malaysia" (ID: FRGS13-001-0242), a Fundamental Research Grant funded by the Ministry of Education, Malaysia.

* Associate Professor, Ahmad Ibrahim Kulliyyah of Laws, International Islamic University Malaysia.

* Ph.D. Candidate, Ahmad Ibrahim Kulliyyah of Laws, International Islamic University Malaysia. 


\title{
MENGAMANAHKAN KUASA PENGUATKUASAAN UNDANG-UNDANG MARITIM KEPADA PENGAWAL PANTAI: BEBERAPA PENGAJARAN BUAT MALAYSIA
}

\begin{abstract}
ABSTRAK
Memandangkan terdapat banyak ancaman maritim disamping peningkatan dalam jenayah maritim, ianya menjadi kemestian buat setiap negara untuk mempunyai pengawal pantai yang mempunyai kuasa penguatkuasaan undang-undang maritim bagi memastikan keselamatan sempadan dan perairan negara terpelihara. Pengawal pantai memainkan peranan penting dalam memastikan keselamatan maritim terjaga dan operasi mereka kini semakin canggih. Malangnya, di Malaysia, Agensi Penguatkuasaan Maritim (APMM) atau dikenali sebagai Pengawal Pantai Malaysia, masih bergelut dengan isu memperolehi kuasa mutlak bagi penguatkuasaan maritim walaupun setelah dua belas tahun ditubuhkan. Kajian ini mendapati bahawa terdapat persaingan senyap antara APMM dengan agensi penguatkuasaan lain di Malaysia. Analisa telah dibuat pada amalan di Amerika Syarikat, India dan Jepun bagi mencari penyelesaian yang bersesuaian untuk mengatasi masalah ini. Kajian ini seterusnya mendapati bahawa punca permasalahan ini ialah pentafsiran yang diberikan kepada seksyen 7(3), Akta APMM yang seharusnya dipinda bagi memberikan kuasa mutlak kepada APMM dan membatalkan hak penguatkuasaan kepada agensi-agensi lain.
\end{abstract}

Kata Kunci: Keselamatan maritim, undang-undang Maritim, APMM, pengawal pantai, polis marin 


\section{INTRODUCTION}

Maritime security is a matter of life and death for a maritime nation like Malaysia. One of the key problems in this respect is enforcing the laws that combat maritime security threats. Since maritime offences are many and varied, maritime law enforcement is in a way, a complicated task. There needs to be an effective and systematic regulatory framework. Coast guards are very famous around the world and many are government bodies responsible for effective maritime law enforcement, while others are merely voluntary institutions contributing mainly in maritime search and rescue.

In Malaysia, the Malaysian Maritime Enforcement Agency (MMEA) has been established since 2004 as the Malaysian version of the coast guard. It was established with the high expectation of developing towards a single maritime enforcement agency, effectively replacing various law enforcement bodies responsible for security and safety of Malaysian maritime zones.

Even after twelve years of its establishment, the MMEA is still struggling to be an effective maritime law enforcement body. The most complicated issue that is facing the MMEA is the unsettled problem concerning proper demarcation of enforcement powers between MMEA and other enforcement bodies such as the marine police, customs, immigration, and the departments of environment and fisheries. A proper analysis is needed to see whether this is due to the lack of clarity in the law itself, i.e., section 7(3) of the MMEA Act, or it is on account of weak implementation of the law in practice. Another issue relates to MMEA's structural defect. Although many of the MMEA officers were originally from the Navy or a few are from the Marine Police, according to the MMEA Act they now become civil servants and they are no longer part of the armed forces. The MMEA itself is not under the Ministry of Defence but it is one of the many divisions of the Prime Minister's Department.

The present article first of all touches on the nature and scope of maritime law enforcement and traces the origin and development of coast guards. The article then concentrates on the rationale behind the establishment of the MMEA, its functions and powers, and makes an assessment of the problems that the Malaysian coast guard is currently facing. This part of the article mainly relies on roundtable discussions and interviews with the officers from MMEA, Royal Malaysian Navy and Marine Police. 
To reflect the international best practices, an analysis is made on the coast guards of three countries. The coast guard of the United States of America is apparently one of the best coast guards in the world, while the position in India is relied on because she has a similar legal and colonial background as Malaysia, and the Japan Coast Guard is famous for its professionalism and sophisticated devices. All of them have coast guards with law enforcement functions. In view of the lessons taken from the analysis of coast guards of these countries, the article concludes with recommendations for the reform of the Malaysian Maritime Enforcement Agency.

\section{MARITIME LAW ENFORCEMENT: NATURE AND SCOPE}

Effective maritime law enforcement plays a crucial role in securing maritime territories and maritime interests of nations. Before defining the term 'maritime law enforcement,' it is important to ascertain the meaning of "law enforcement" itself. The term 'law enforcement' can be defined as "ensuring obedience to the laws."

Law enforcement functions are undertaken by law enforcement agencies, ${ }^{2}$ which are in charge of law enforcement and law enforcement officers or authorities who are "responsible for the prevention, investigation, apprehension or detention of individuals suspected or convicted of offences" ${ }^{\prime 3}$ against national and international laws. Law enforcement powers of States play a very important role in suppressing maritime security threats.

Maritime law enforcement encompasses surveillance, stopping and boarding vessels, search or inspection, reporting, arrest or seizure of persons and vessels, detention, and formal application of law by judicial or other processes, including the imposition of sanctions. ${ }^{4}$ In order to protect and secure maritime territories and maritime interests

The Free Dictionary, http://www.thefreedictionary.com/law+enforcement, accessed January 12, 2016.

2 Kären M. Hess, Christine Hess Orthmann, Introduction to Law Enforcement and Criminal Justice (New York: Delmar, 10th ed., 2011), 1.

3 USLEGAL: Legal Definition of Law Enforcement Officer, available at http://definitions.uslegal.com/l/law-enforcement-officer/ accessed January 12, 2016.

$4 \quad$ William T. Burke, The New International Law of Fisheries: UNCLOS 1982 and Beyond, (Oxford: Clarendon Press, 1994), at 303. 
of the nations, it is crucial to have efficient bodies which are capable of effective maritime law enforcement.

Types of maritime law enforcement agencies can vary from one country to another. Among them, coast guard organisations are found to be popular, particularly in playing their roles of maritime law enforcement. On the other hand, there are coast guards which are not authorised to exercise law enforcement functions. Rather, they are just volunteer organisations merely providing search and rescue services.

\section{THE ROLE OF COAST GUARDS: AN ANALYSIS}

The concept of coast guard is not a new one. It has historical roots. In the United Kingdom, for example, the Her Majesty's Coastguard (HMC) owes its origins to the efforts made to combat smuggling throughout the 17th and 18th centuries. The Board of Customs and the Board of Excise were responsible for the prevention of the evasion of duty by smuggling and by the end of the 17th century they had a small fleet of boats and a few men on the coast. In 1809, a Preventative Water Guard was established, which can be said as the genesis of the modern British coastguard. ${ }^{5}$

At the present time, coast guards are so popular that there are 166 entities identified as coastguards among the 193 members of the United Nations. ${ }^{6}$ The role of coast guards varies according to the needs of the country. It may range from the basic function of maritime search and rescue to maritime law enforcement and maritime security. While there are a few coast guards which are civilian bodies functioning on a voluntary basis with the primary responsibility of search and rescue, there are many others which are government bodies with maritime law enforcement powers and are functioning as part of the armed forces of the nation.

The best examples of coast guards whose function is search and rescue on a voluntary basis without any maritime law enforcement powers can be found in Australia and New Zealand. The Australian Volunteer Coast Guard (AVCG), for example, was formed in 1961,

5 "Coastguard History, The Origins of HM Coastguard," (1992 Memorandum, the National Archives), available at http://yourarchives.nationalarchives.gov.uk /index.php?title=Coastguard_History, accessed April 9, 2016.

6 Ibid. 
modelled on the US Coast Guard Auxiliary. It is a voluntary civilian organisation of men and women and it aims to provide "safety on the waterways, train boat users in all aspects of safe small boat handling and contribute effectively to the search and rescue operations.",

The AVCG has no authority to exercise maritime law enforcement empowered under the exclusive legislation and they mainly function as maritime search and rescue agencies. It is found that the several agencies including private contractors are involved in Australian maritime law enforcement. The protection of Australia's national maritime interests is a multi-faceted challenge including prevention of potential aggressors crossing Australia's maritime approaches as well as deterring criminal activities in Australian's maritime zones. The Australian Defence Force which includes the Australian Navy, Army and Air Force, is found to be the primary government organisation responsible for meeting such challenges with the contribution of other "agencies such as Customs, Australian Fisheries Management Agency (AFMA), Immigration, Australian Quarantine Inspection Service, Australian Federal Police and state police services." 8

There was a plan to create an exclusive coast guard for Australia in order to exercise effective maritime law enforcement. However, the plan was not supported by the government, accentuating the fact that the force would be inadequate to meet the need and would be prohibitively expensive. ${ }^{9}$

The second example would be the Royal New Zealand Coast Guard. The first practice of coast guard in New Zealand can be traced back to the late 19 century. Its functions were started by establishing independent rescue services "to rescue people from maritime tragedy, and to prevent such tragedies from occurring at all." Due to New

7 http://www.coastguard.com.au/history-2010/history-early-days, accessed March 28, 2016.

8 R.M. Warner, “Australia's Maritime Challenges and Priorities: Recent Developments and Future Prospects" in J. Ho, \& S. Bateman, (ed), Maritime Challenges and Priorities in Asia: Implications for Regional Security (2012) 251-271. See also Submission on the Review of Coast watch by the Australian Defence Association to The Joint Committee of Public Accounts and Audit of the Australian Parliament. Melbourne, April 2000. http://www.aphref.aph.gov.au-house-committee-jcpaa-coastwatch-submissionsada.pdf, accessed March 28, 2016

9 Prabhakaran Paleri, Coast Guards of the World and Emerging Maritime Threats, (Tokyo: Ocean Policy Research Foundation, 2009), 58. 
Zealand's rugged coastline, local boaters were aware that they needed to take necessary actions for the safety of the people. Therefore, a group of volunteers set up a unit with special focus on saving lives at sea. The coast guard is a purely volunteer organisation with charitable status with the primary function of maritime search and rescue. ${ }^{10}$

The unique character of the Royal New Zealand Coast Guard is that it runs by charity fund, makes no profit, is neither a military nor security organisation, and unlike other coastguards, it is not part of the government or armed forces. In addition, it does not possess any kind of law enforcement power authorised under specific legislation which is the major difference from common coast guard organisations.

When it comes to maritime law enforcement, there are two specialist Police Maritime Units in New Zealand. One is in Auckland and the other in Wellington. They carry out a wide range of activities, including: investigating and reporting offences, apprehending offenders, search and rescue, increasing national security through joint enforcement patrols with other government agencies such as Customs, Immigration, Department of Conservation, Maritime New Zealand, and Ministry of Transport. ${ }^{11}$ In fact, multiple agencies are involved in maritime law enforcement of New Zealand as in the case of Australia. Although there is a coast guard in New Zealand, it is not performing functions of coast guards, particularly maritime law enforcement. $^{12}$

On the other hand, many coast guards of the world are employed in law enforcement activities for the protection of national sovereignty and maritime security. ${ }^{13}$ It is therefore not surprising that Paleri defines a coast guard as "a maritime agency of a nation or a geostrategic entity which performs law enforcement in home waters

\footnotetext{
10 https://www.coastguard.nz/about-us/our-history/, accessed March 29, 2016.

11 New Zealand Police Maritime Unit, available at http://www.police.govt.nz/about-us/structure/teams-units/maritime-units, accessed April 10, 2016.

12 Eris Tajudin, Study of Managerial Challenges Confronting a New Agency: The Case of the Malaysian Maritime Enforcement Agency, Master Thesis, Naval Postgraduate School, (June 2015), 33.

13 Dirham Dirhamsyah, "Maritime Law Enforcement and Compliance in Indonesia: Problems and Recommendations," Maritime Studies, SeptemberOctober 2005, (Research Online: University of Wollongong), 12, available at http://ro.uow.edu.au/lawpapers/248, accessed April 4, 2016. See, for example, coastguards of the United States, the United Kingdom, Japan, and India.
} 
and in any identified areas of interest empowered under the legislation that is also acceptable under international law."14

There are several advantages of having a national coast guard as a separate law enforcement body. First of all, the overlapping of functions and jurisdictions among various enforcement agencies can be avoided. Coast guard officers or law enforcement personnel are required to possess the wide enforcement powers of all available national maritime laws in a nation's waters. ${ }^{15}$

Moreover, it is more suitable for the coast guard's vessel rather than warships to perform law enforcement functions in sensitive maritime areas where conflicting maritime claims are present, for example, the South China Sea. ${ }^{16}$ In such situations, law enforcement activities such as arrest by warships could stimulate enmity among conflicting nations. Moreover, coast guard's vessels are "less threatening than larger, more heavily armed haze gray warships" ${ }^{\prime 17}$.

Another advantage relates to cost effectiveness. Coast guards' vessels are essentially low cost compare to navy ships. The navy is a military force and its vessels are large, with high technology, and are extremely expensive. ${ }^{18}$ As an additional benefit, the coast guard as a civil organisation may request funding support from international aid agencies to acquire new vessels. ${ }^{19}$

Paleri, Coast Guards of the World, 53.

Sam Bateman, "Coast Guards: New Forces for Regional Order and Security," Asia Pacific Issues, no 65, (Honolulu: East-West Center, January 2003), 2-3.

Currently, there are challenging maritime territorial disputes in the South China Sea, involving Brunei, China, Malaysia, Taiwan, Philippines and Vietnam. See, for example, Prashanth Parameswaran, "Playing It Safe: Malaysia's Approach to the South China Sea and Implications for the United States", Maritime Strategy Series, February 2015; M.J, Valencia, China and South China Sea Disputes: Conflicting Claims and Potential Solutions in the South China Sea, (Oxford: Oxford University Press, 1995); Ian James Storey, "Creeping Assertiveness: China, the Philippines and the South China Sea Dispute," Institute of South East Asia Studies, vol.21, no.1, (1999): 95-118; Peter, Dutton, "Three Disputes and Three Objectives: China and the South China Sea," Naval War College Review 64.4 (Autumn 2011): 42-67; M. Taylor Fravel, "China's Strategy in the South China Sea," A Journal of International and Strategic Affairs, vol.33, no.3 , (2011): 292-319.

17 Scott C, Truver, "The World is Our Coastline." USN Institute Proceedings, June 1998, 45.

18 Alok Bansal, "Synergising Indian Navy and the Coast Guard," Journal of Defence Studies, vol. 2 No. 1, (Summer 2008): 94.

19 Bateman, "Coast Guards," 3. 
In addition, the establishment of an integrated law enforcement agency, a national coast guard, can bring all the maritime aspects of law enforcements under one roof. In this way, maritime law enforcement of a nation can become more effective since only one agency is handling all matters including countering maritime crimes, monitoring and surveillance of fisheries, customs and immigration sectors. Moreover, there can be advantages from cooperation among coast guard organisations such as having joint trainings and law enforcement exercises which might not be available from naval cooperation. $^{20}$

From the above analyses, it is obvious that there are several advantages of coast guards with law enforcement functions. However, establishing a coast guard as a single maritime law enforcement body with various law enforcement responsibilities may have challenges since it requires varied technical and professional skills, in a single agency. $^{21}$

Maritime security is multi-faceted and maritime threats are many and varied. When a coast guard is entrusted with maritime enforcement powers, it definitely has to encroach on the domains of many other agencies relating to marine, customs, immigration, environment, fisheries, and transportation. It is therefore imperative that a systematic and well-adjusted regulatory framework is in place. Against this background, an analysis will be made on the efficacy of the Malaysian Maritime Enforcement Agency as a coast guard entrusted with maritime law enforcement.

\section{THE MALAYSIAN MARITIME ENFORCEMENT AGENCY (MMEA): THE MALAYSIAN VERSION OF COAST GUARD}

The origin of the Malaysian Maritime Enforcement Agency (MMEA), commonly known as the Malaysian coast guard, owes to a study undertaken by the National Security Council of the Prime Minister's Department in April 1999. The outcome of the study was that "the maritime enforcement in Malaysia was not effective due to

$\begin{array}{ll}20 & \text { Ibid. } \\ 21 & \text { Ibid. }\end{array}$ 
the involvement of too many agencies with overlapping functions, overlapping jurisdiction and uneconomical use of resources.",22

Prior to the establishment of the MMEA, there were twelve (12) different agencies performing law enforcement functions in the Malaysian Maritime Zones, namely: Marine Operation Force of the Royal Malaysia Police, Department of Immigration, Royal Malaysian Navy, Royal Malaysian Air Force, Marine Department of Peninsular Malaysia, Marine Department of Sabah and Sarawak, Department of Fisheries (DOF), Royal Malaysian Customs Department, Department of Environment, Department of Lands and Mines Mineral and Geoscience Department and Maritime Enforcement Coordination Centre. ${ }^{23}$

The idea at that time was that the involvement of multiple agencies in Malaysian maritime enforcement created duplicities in roles, overlapping of functions and jurisdictional areas, unhealthy competition in assets procurement, and the under-utilization of assets and human resources. Therefore, it was believed that the establishment of the MMEA was needed to bring all the agencies and assets together under the single maritime enforcement agency and that it was also the best solution to save nation's money and resources by focusing only on single agency and the law enforcement can be more effective. $^{24}$

The MMEA was formally established with the enactment of the Malaysian Maritime Enforcement Agency Act of 2004. ${ }^{25}$ Since the MMEA became a fully operational agency on 30 November, 2005, it has been placed under the Prime Minister's Department of Malaysia. The MMEA is headed by a Director General appointed by the Yang Di Pertuan Agong on the advice of the Prime Minister. ${ }^{26}$ The officers

22 Irwin, U.J. Ooi, "The Malaysian Maritime Enforcement Agency Act 2004: Malaysia's Legal Response to the Threat of Maritime Terrorism," Australian \& New Zealand Maritime Law Journal, 21(2007): 71. See also http://www.malaysiacentral.com/information-directory/malaysian-maritimeenforcement-agency-agensi-penguatkuasaan-maritim-malaysiamalaysia/\#sthash.LIzVanpB.dpbs, accessed January 2, 2016. Irwin, "The Malaysian Maritime Enforcement Agency Act 2004," 71.

24 See Tim Lynch "Malaysian Maritime Enforcement Agency: A Modern Coast Guard Model," Front Line Security, Vol 7, No. 1 (2012), 22, at 23, available at http://infolynk.ca/bcfishing/MMEA-TimLynch.pdf, accessed on 12 March 2016. Malaysian Maritime Enforcement Agency Act, 2004, Laws of Malaysia, Act 663 , date of publication in the Gazette- I July 2004, date of coming into operation- 15 February 2005. 
and other ranks of the MMEA are appointed by the Public Service Commission as Maritime Enforcement Service officers ${ }^{27}$ and are considered civil servants under the Malaysian Civil Service. Although former navy or marine police officers can be recruited, MMEA is clearly not part of the armed forces and its officers are not military officers. This is a clear deviation from other established coast guards like the United States Coast Guard (USCG) and the Indian Coast Guard (ICG). ${ }^{28}$

In accordance with the MMEA Act 2004, the MMEA is to be employed in the Malaysian Maritime Zone "for the maintenance of law and order, the preservation of the peace, safety and security, the prevention and detention of crime, the apprehension and prosecution of offenders and the collection of security intelligence." 29 The functions of the MMEA are to be exercised in the Malaysian Maritime Zone which includes the internal waters, territorial sea, continental shelf, exclusive economic zone and the Malaysian fisheries waters and includes the air space over the zone."30 A controversial provision is that the jurisdiction of the MMEA is not strictly limited to the maritime zones but it also extends to the air space over each of aforementioned zones, ${ }^{31}$ and as such there appears to be a clash with the general international law principle that a State cannot exercise territorial jurisdiction over the airspace above the exclusive economic zone as it is subject to freedom of overflight of other States. ${ }^{32}$

Section 5(1), ibid.

Nevertheless, MMEA must operate "under the general command and control of the Armed Forces of Malaysia during any period of emergency, special crisis or war." See section 17(1), ibid. This is in accord with the general practice of other established coast guards of the world.

29 Section 3 (2), ibid.

30 Section 2, ibid.

31 Extension of jurisdiction to the air space is also found in the Civil Aviation Act 1969 (Malaysia) (Act 3) s 2and Court of Judicature Act 1964 (Act 91) s 3. For a commentary, see Irwin, U.J. Ooi, "The Malaysian Maritime Enforcement Agency Act 2004: Malaysia's Legal Response to the Threat of Maritime Terrorism," Australian \& New Zealand Maritime Law Journal, 21 (2007): 71.

32 See articles 57 and 87, United Nations Convention on the Law of the Sea, 1982. 


\section{Functions and powers}

There are eight distinct functions of the MMEA enumerated under the MMEA Act $2004 .^{33}$ The very first function of the MMEA which is stated in Section 6 of the Act is, "to enforce law and order under any federal law." ${ }^{34}$ Regarding enforcement powers of the MMEA, the following is the remark made by an Officer of the MMEA:

MMEA can exercise its enforcement powers in the Malaysian Maritime Zone wherever there is any available federal law. For example, MMEA can enforce Penal Code in the territorial sea and Fisheries Act and other relevant and applicable federal laws in the exclusive economic Zone (EEZ) and even sometimes on the High Seas since there is no clear definition of the High Seas in the United Nations Convention on the law of the sea (UNCLOS) $1982 .{ }^{35}$

MMEA, through exercise of its enforcement powers, is empowered to investigate any offence which it has reason to believe is being committed, or is about to be committed or has committed, ${ }^{36}$ as well as "to arrest any person whom it has reason to believe has committed an offence." ${ }^{37}$ Such powers of investigation and arrest exercised by the MMEA must of course comply with the legal requirements of the Criminal Procedure Code ${ }^{38}$ In addition, MMEA is empowered to demand the production of any license, certificate or any other document for inspection. ${ }^{39}$ For example, the MMEA can assist the Fisheries Department and the Marine Department in the enforcement of licensing requirements under the Fisheries Act 1985 and the Merchant Shipping Ordinance 1952. Moreover, MMEA can also exercise the right of hot pursuit in accordance with international law. ${ }^{40}$

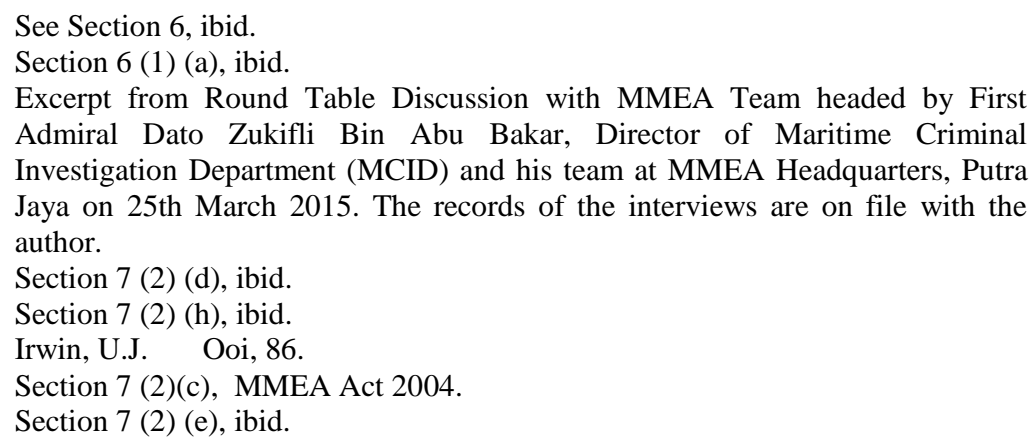



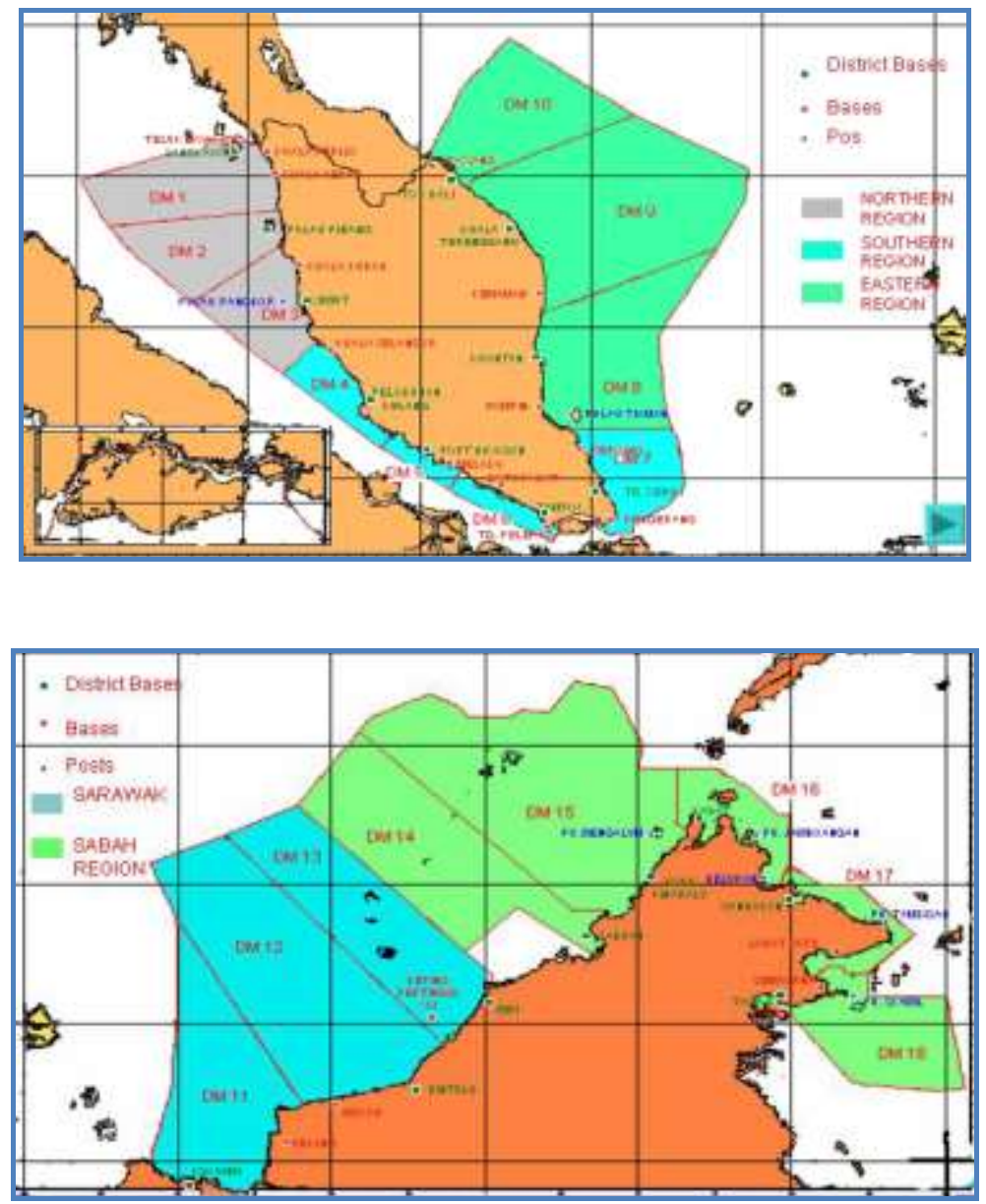

Figure 1.Operational Areas of the Malaysian Maritime Enforcement Agency Source: (MMEA)

The exercise of enforcement powers: singly or in combination with other agencies?

The most controversial provision of the MMEA Act is its section 7(3), which provides that "an officer of the MMEA shall have, for the purpose of this Act, all the powers which any relevant agency may exercise under any federal law which is applicable in the Malaysian 
Maritime Zone." ${ }^{41}$ "Any relevant agency' in this context means "a body or agency that is for the time being responsible in Malaysia for the enforcement of any federal law which is applicable in the Malaysian Maritime Zone." This term refers to enforcement bodies like the marine police and officers from departments of marine, fisheries, and environment.

It appears to be the intention of the drafters of the MMEA Act to establish a single integrated maritime law enforcement agency which is empowered to enforce Malaysian federal laws within the maritime zones of Malaysia as well as in the airspace over the zones. $^{42}$ However, although the intention of the establishment of the MMEA was to transform from the piecemeal approach to a holistic approach of maritime law enforcement in Malaysia, MMEA is still facing challenges regarding the complete transformation to a sole maritime law enforcement agency.

The controversy stems from the lack of a clear exclusion in section 7(3) of the Act, of other 'relevant agencies' from exercising any maritime law enforcement powers. Although the section is interpreted by the MMEA as excluding the enforcement power of other enforcement agencies, ${ }^{43}$ this line of thinking is not accepted by other relevant agencies and they understand the section as not excluding their power of enforcement. This is, in particular, the way of interpreting the section by the Marine police. The view of a highranking marine police officer is as follows:

In the past, the territory within which the marine police had law enforcement power was limited to ports areas, rivers, coastal areas and islands. However, at the National Security Council Special Meeting on 28 January 2014, it was decided that there would be no bar as to the territorial limits for marine police to exercise maritime

41 Section 7(3), ibid. Section 16, which provides that "The Agency and the relevant agencies shall closely coordinate, consult and liaise with each other and render to each other assistance for carrying out the provisions of this Act," is only meant for coordination among the various maritime law enforcement agencies.

42 Tim Lynch "Malaysian Maritime Enforcement Agency: A Modern Coast Guard Model," 22, at 26; see also Irwin, "The Malaysian Maritime Enforcement Agency Act 2004," 71.

43 See Excerpt from Round Table Discussions with MMEA Team headed by First Admiral Dato Zukifli Bin Abu Bakar, Director of Maritime Criminal Investigation Department (MCID) and his team at MMEA Headquarters, Putra Jaya on 25th March 2015. The records of the Roundtable Discussions are on file with the author. 
law enforcement. Therefore, we are moving towards to secure our maritime territories with whatever assets we have (we have for the time being 136 patrol craft, after surrendering a few to MMEA). ${ }^{44}$

The latter interpretation is supported by the fact that there is no provision in the MMEA Act that prevails over any contrary provisions in other federal laws. It means that the provisions of other federal laws that empower maritime law enforcement to other relevant agencies are not derogated by the MMEA Act and are still operating laws.

Not only is there the lack of a provision in the statute with respect to the clear division of powers between MMEA and other enforcement agencies but also lack of clear guidelines on the part of the Government in its implementation has exacerbated the situation and leads to the duplication of functions and powers among them. In fact, in the beginning and at the time of the establishment of the MMEA, the Government instructed other law enforcement agencies like the marine police, customs and fisheries departments to hand over their patrol vessels and assets to the MMEA. ${ }^{45}$ Although a few vessels were handed over, the response seemed to be a bit halfhearted. There was a complaint by the MMEA that it got only old and outdated vessels. ${ }^{46}$ It seems that there is this idea of mild resistance to the establishment of a single maritime law enforcement body on the part of some other enforcement agencies.

To take one striking example of duplication and overlapping of maritime law enforcement powers, MMEA has jurisdiction over fisheries related offences to do "examination, seizing and disposing of any fish, article, device, goods, vessel, aircraft, or any other item relating to any offence which has been committed or it has reason to believe has been committed." ${ }^{47}$ At the same time, According to

44 Interview with ACP Abdul Rahim Bin Abdullah (Deputy Commander of the Marine Police, Operations/Intelligence) on 28 April 2015 at Royal Malaysian Police Force Headquarters, Bukit Aman, Kuala Lumpur. The records of the interview is on file with the author. Ibid.

46 See Excerpt from Round Table Discussions with MMEA Team headed by First Admiral Dato Zukifli Bin Abu Bakar, Director of Maritime Criminal Investigation Department (MCID) and his team at MMEA Headquarters, Putra Jaya on 25th March 2015. The records of the Roundtable Discussions are on file with the author.

47 Section 7(2)(f), ibid. 
section 46 of the Fisheries Act 1985, the Director General of the Fisheries Department and fisheries officers are the authorised officers to exercise enforcement powers under the Fisheries Act relating to arrest, seizure and detention of fishing vessels. ${ }^{48}$ In practice also Fisheries Department is currently exercising law enforcement powers pertaining to the Fisheries Act and thus creating overlapping powers with the MMEA. With regard to this, the commentary of an officer of the MMEA is as follows:

MMEA is having problems with the Fisheries Department regarding law enforcement powers. They are still doing law enforcement actions such as arresting the fishermen (local or foreign). They were told not to but they are still doing it. So, MMEA is having a tough time with the Fisheries Department. ${ }^{49}$

\section{Challenges Relating to Financial Constraints, Assets and Manpower}

Apart from the duplication of functions and overlapping powers with other law enforcement agencies, MMEA is facing other challenges such as financial constraints, assets and manpower to perform the effective maritime law enforcement. As seen earlier, the patrol vessels and assets handed over by other law enforcement agencies are said to be old and outdated. At the same time the budget allocations by the government is very limited to purchase new and sophisticated patrol boats and other vessels. ${ }^{50}$

Strong financial support by the government is necessary in order to purchase sufficient and capable vessels, sophisticated facilities, as well as to recruit expert law enforcement officers which will contribute to effective enforcement functions. The MMEA must overcome all such challenges to achieve its ultimate aim of becoming a successful coast guard agency for the nation. In doing so, it is important for the MMEA to learn from international best practices with successful coast guard organisations. It can be seen later that the

\footnotetext{
48 Section 46, Fisheries Act, 1985.

49 Excerpt from Round Table Discussions with MMEA Team headed by First Admiral Dato Zukifli Bin Abu Bakar, Director of Maritime Criminal Investigation Department (MCID) and his team at MMEA Headquarters, Putra Jaya on 25th March 2015. The records of the Roundtable Discussions are on file with the author. Ibid.
} 
United States and Japan have overcome such challenges and achieved the aim of making their coast guards as truly the sole agency responsible for all the matters related to maritime law enforcement. ${ }^{51}$

\section{INTERNATIONAL BEST PRACTICES}

The majority of coast guards of the world has law enforcement functions and the following is an evaluation of the practice of a few selected countries for Malaysia to take lessons.

\section{United States Coast Guard (USCG)}

The United States Coast Guard (USCG) was established by an Act of Congress on January $28,1915^{52}$ and is widely believed as the worlds earliest. It is "a military, multi-mission, maritime service..... and one of the nation's five Armed Services." 53 According to Title 14 of the US Code, "the Coast Guard is a military service and a branch of the Armed Forces of the United States at all times" ${ }^{\text {"54 }}$. When the USCG was first introduced, "it was placed under the Treasury Department as the law enforcement agency which collected tariffs and taxes at sea." $" 55$ The USCG was transferred to the Department of Homeland Security on March 1, 2003. ${ }^{56}$ Although the USCG operates under the DHS in times of peace, it can be transferred to operating under the Department of the Navy in time of war. ${ }^{57}$

51 Sutarji Kasmin, "Enforcing Ship-Based Marine Pollution for Cleaner Sea in the Straits of Malacca,"Environment Asia 3 (special issue) (2010), 64.

52 Ibid, 101.

53 S.B. Bruce, and S.C. Truver, "America's Coast Guard: Safeguarding US Maritime Safety and Security in the 21st Century", (Washington DC: US Coast Guard HQ, 2000), 1. The five Armed Services are: Army, Navy, Air Force, Marine and Coastguards. See "Coast Guard 2020: Ready Today...Preparing for Tomorrow"(Washington, D.C.: U.S. Coast Guard, 1998), 1, 3.

54 US Code: Title 14- Establishment of Coast Guard, available at https://www.law.cornell.edu/uscode/text/14/1, accessed April 4, 2016.

55 Eris Tajudin, "Study of Managerial Challenges Confronting A New Agency: The Case of The Malaysian Maritime Enforcement Agency," MBA Professional Report, June 2015, Naval Postgraduate School, Monterey, California, 27.

56 Paleri, Coast Guards of the World, 101.

57 Tajudin, "The Case of the Malaysian Maritime Enforcement Agency," 29. 
A unique character of the USCG is that it has law enforcement powers in the territorial sea as well as on the high seas. ${ }^{58}$ Moreover, it is "simultaneously an armed force of the United States and a federal law enforcement agency." The core focuses of the USCG include: "national and maritime security, preserving national resources, maritime safety, maritime mobility, and national defense." $" 59$

"Maritime security" is key to the USCG's functions. It has authority "to board any vessel subject to the US jurisdiction or to the operation of US law, to do inspections, examinations, searches, seizures, and arrest upon the high seas and waters over which the US has jurisdiction." 60 It has broad law enforcement powers and "it enforces or assists in enforcing federal laws, treaties, and other bilateral and multilateral agreements on waters subject to the US jurisdiction and on the high seas as a primary maritime law enforcement agency." While undertaking law enforcement against illegal migration to the United States, the coast guard performs Search and Rescue (SAR) operations and it is evidenced that many of their undocumented immigrant interdictions start with SAR operations.

Moreover, it is the function of the USCG to secure port security and harbour defense as a key component of national defense operations. The main purpose of sustaining port security is to protect the potential attacks against coastal and port facilities by the terrorists and they also believe that denying terrorists' entry and use of United States maritime domain would ensure the Nation's security. The Coast Guard's authorities over port securities have been strengthened with the establishment of the Maritime Transportation Security Act (2002). ${ }^{61}$ According to the Act, Coast Guard's captains of the Port became the Federal Maritime Security Coordinators (FMSC). Therefore, the Coast Guard has taken the lead role in all the coordinating maritime security operations in United States' ports and waterways. $^{62}$

As far as the law enforcement against piracy is concerned, the US Coast Guard has been requested by combatant commanders "to

\footnotetext{
58 Ibid, 25.

59 Ibid.

60 "Doctrine for the US Coast Guard," Coast Guard Publication 1, (Washington. D.C: US Coast Guard Headquarters, 2014), 11.

61 Maritime Transportation Security Act, 2002, United States, PUBLIC LAW 107295, Nov. 25, 2002 (116 STAT. 2064).

62 "Doctrine for the US Coast Guard," 15.
} 
conduct at sea-interceptions and anti-piracy operations, foreign liaison, and other supporting warfare tasks in all key theaters." ${ }^{63}$

The US Coast Guard performs not only law enforcement activities against the maritime security threats but also undertakes preventive operations from occurring these threats within their maritime domain. Moreover, the characteristic of the US Coast Guard is not different from the navy since it is also an armed force with special national defense capabilities such as "maritime interception and interdiction, military environmental response, port operation, security and defense, rotary wing air intercept, combating terrorists and Maritime Optional Threat Response support." ${ }^{, 64}$ It can perform law enforcement activities effectively for each and every maritime security threat without calling the help from the navy. Therefore, it would not be wrong to say that the US Coast Guard is one of the most established and efficient coast guards of the world.

\section{The Indian Coast Guard (ICG)}

The genesis of the Indian Coast Guard (ICG) can be traced back to its formation as part of the Navy on February 1, 1977. It was formally established as an independent organisation on August 19, 1978 with the enactment of the Coast Guard Act 1978. ${ }^{65}$ Since its inception, "the Indian Coast Guard has acquired a wide range of capabilities both surface and airborne to fulfil the assigned functions during peace time as well as to join the Indian Navy during war." under the Ministry of Defence and according to the Indian Constitution it is an armed force of the Union apart from the navy, military, and air forces. The position of the ICG as an armed force is very similar to that of the $\mathrm{USCG}^{67}$

It is noteworthy that the Indian Coast Guard is similar to the United States Coast Guard in respect of organisational structure. The only difference is that the ICG has always been under the MOD while the USCG has later been transferred to the Department of Homeland

\footnotetext{
63 Ibid, 14.

64 Ibid, 13.

65 The Coast Guard Act, 1978 (India Act No. 30 of 1978) Notified vide SRO 10(E) dated 18 Aug 1978. Gazette of India Pt. II, sec 4, p. 16.

66 Indian Coastguard, available at http://mod.gov.in/writereaddata/ AR_2013/Eng/ch6.pdf, accessed March 27, 2016.

67 Alok Bansal, "Synergising Indian Navy and the Coast Guard," Journal of Defence Studies, vol. 2 No. 1, (Summer 2008), 80-82.
} 
Security (DHS) ${ }^{68}$ "The ICG is an independent non-military armed force which will act under the command and control of the Navy during war." $" 69$

According to section 14(1) of the Coast Guard Act 1978, the primary responsibility of the ICG is "to protect by such measures, as it thinks fit, the maritime and other national interests of India in the maritime zones of India." 70 Section 14(2) of the Coast Guard Act 1978, enumerates the functions and powers of the ICG as follows:

"(a) ensuring the safety and protection of artificial islands, offshore terminals, installations and other structures and devices in any maritime zone;

(b) providing protection to fishermen including assistance to them at sea while in distress;

(c) taking such measures as are necessary to preserve and protect the maritime environment and to prevent and control marine pollution;

(d) assisting the customs and other authorities in anti-smuggling operations;

(e) enforcing the provisions of such enactments as are for the time being in force in the maritime zones; and

(f) such other matters, including measures for the safety of life and property at sea and collection of scientific data, as may be prescribed." 71

The ICG is a well-established Coast Guard which plays an important role in sustaining national as well as maritime security since its ultimate missions are to ensure "EEZ security, coastal security, offshore security, marine safety, marine environment protection, scientific assistance, and national defense." $" 72$ Although the ICG is not a military organisation, it is found to be unique for existing

68 Tajudin, "The Case of the Malaysian Maritime Enforcement Agency," 31.

69 Paleri, Coastguard of the World, 74.

70 Section 14 (1), Coast Guard Act 1978.

71 Section 14 (2), ibid. See for the commentary, Prabhakaran Paleri, "Role of the Coast Guard in Marine Environment Security: The P3C Factors," Paper presented at Oil Spill Management Workshop held at Goa on 19-20 Jul 02, available http://www.indiancoastguard.nic.in/Indiancoastguard/NOSDCP/NOSDCP\%20P ublications_files/p3.pdf, accessed March 29, 2016.

72 http://joinindiancoastguard.gov.in/cgmission.html, accessed on 27 March, 2016. 
under the same Ministry (MOD) as the Navy. "The long coastline, compounded with the large area of maritime territory and the EEZ, are why the ICG should be placed with the Navy under the Ministry of Defense." 73 In exercising law enforcement functions, the territorial sea is the maritime zone where both the Navy and the ICG operate. Smuggling, illegal immigration, and poaching in the exclusive economic zone are handled by the ICG. ${ }^{74}$ There is coordination between the Navy and the Coast Guard in undertaking maritime patrol and surveillance of the entire coastline. ${ }^{75}$

\section{The Japan Coast Guard (JCG)}

The Japan Coast Guard (JCG) was established in May 1948 under the Japan Coast Guard Law. ${ }^{76}$ Its motto is "Keeping the Oceans Safe and Enjoyable for Future Generations!" The following are its primary functions as laid down in the Law:

The Japan Coast Guard shall, for the purpose of ensuring safety and order at sea perform the duties concerning enforcement of laws and regulations at sea, maritime search and rescue, prevention of maritime pollution, prevention and suppression of crimes at sea, detection and arrest of criminals at sea, regulation of vessels' traffic at sea, services concerning hydrography and aids to navigation, other services for ensuring maritime safety and the services concerning matters incident thereto. ${ }^{77}$

An analysis of the law and practice of the Japan Coast Guard clearly demonstrates two important points from which Malaysia can take lessons. The first point is the clear and unequivocal handing over of

73 Prabhakaran Paleri, Role of the Coast Guard in the Maritime Security of India, Second Edition (New Delhi: Knowledge World, 2007), 7-8; Prabhakaran Paleri, "Changing Concept of National Security and a Maritime Model for India," Ph.D. Thesis (Chennai: Department of Defence and Strategic Studies, University of Madras, February 2002), 167; Tajudin, "The Case of the Malaysian Maritime Enforcement Agency," 31.

Ibid.

Indian Coastguard, http://mod.gov.in/writereaddata/AR_2013/Eng/ch6.pdf, accessed on 27 March, 2016.

Japan Coast Guard Law (Law No. 28 of April 27, 1948 as amended through

Law No. 102 of 1999), available at https://nippon.zaidan.info/ seikabutsu/2001/00500/contents/00021.htm. Accessed on 9 June2016.

Ibid, section 2(1). 
all law enforcement powers held by the previous agencies to the Japan Coast Guard by the law itself. Section 2(2) of the Japan Coast Guard Law provides that:

Those functions heretofore under the jurisdiction of the Secretariat of the Minister of Transport. Director Generals Secretariat of the General Maritime Bureau of Ministry of Transport, Bureau of Shipping, Ship Bureau, Bureau for Seafarers, Commissions for Marine Accidents Inquiry, Lighthouse Bureau, Hydrographic Bureau or those functions of other administrative authorities which are mentioned in the preceding paragraph shall be placed under the jurisdiction of the Japan Coast Guard. ${ }^{78}$

This is a clear guideline for how to amend the controversial provision of section 7(3) of the Malaysian MMEA Act 2004.

The second important point is the state of the art facilities, devices and budget support of the government for Japan Coast Guard. The JCG has altogether 455 vessels and marine craft (including patrol vessels, special guard and rescue craft, and hydrographic survey vessels). In addition, the JCG has 74 aircraft and helicopters, which are indispensable in maritime law enforcement and search and rescue services. ${ }^{79}$ We can very well compare this with a small number of very old and outdated vessels and marine craft owned by MMEA.

\section{SUGGESSTIONS AND RECOMMENDATIONS}

We have seen earlier the problems and challenges of the Malaysian Maritime Enforcement Agency to be an effective maritime law enforcement agency. Taking lessons from the experience of USCG, ICG and JCG as successful maritime law enforcement bodies, the following are suggestions for MMEA:

(1) The controversial section 7(3) of the MMEA Act, which states that "an officer of the Agency shall have, for the purpose of this Act, all the powers which any relevant agency

\footnotetext{
78 Ibid, section 2(2).

79 "Japan Coast Guard: Keeping the Oceans Safe and Enjoyable for Future Generations!", available at http://www.kaiho.mlit.go.jp/e/pamphlet.pdf, accessed on 9 June 2016.
} 
may exercise under any federal law which is applicable in the Malaysian Maritime Zone," should be amended as it clearly does not take away the powers of the other agencies under other Federal laws and thus creates overlapping powers. In this respect, the Japan Coast Guard Law is the best solution ${ }^{80}$ and the amended MMEA Act should clearly provide that maritime law enforcement powers exercised by these agencies shall hereby be entrusted to the MMEA.

(2) Mere amendment to the law will not be adequate. It is imperative that if the policy of the Government is to make the MMEA to be the sole maritime law enforcement agency, the multifaceted contribution and support of the government in the achievement of this objective will also be required.

(3) The issue of structural defects can be solved by changing the regulatory framework of the MMEA. It is suggested that the MMEA should be stationed under the Ministry of Defence rather than under the Prime Minister's Department. This is following the best practice of the USCG and ICG by placing the coast guard as one of the armed forces of the nation and making its officers part of the military service. To this end, sections 4 and 5 of the MMEA Act should be amended. ${ }^{81}$ In this way the MMEA itself and its officials shall enjoy the same prestige, privileges and facilities of armed forces of the nation like Army, Navy and Air Force.

(4) The third suggestion can at the same time take care of the financial, manpower and physical weaknesses. As part of the armed forces of the nation, the MMEA will be entitled to enjoy the same military budget under the Ministry of Defence and can have state of the art vessels, aircraft, helicopters and other technological devices to become an efficient coast guard safeguarding maritime security of Malaysia.

\footnotetext{
80 See section 2(2), Japan Coast Guard Law.
}

81 Section 4 deals with Appointment of the Director General to head the Agency and provides that the DG and other officers are or part of the "Public Service." Section 5 is about the appointment of other officers of the agency. 


\section{CONCLUSION}

Effective maritime law enforcement plays a crucial role in securing maritime zones and protecting maritime interests of nations. Due to many and varied maritime threats and the growing number of maritime crimes, it is necessary for maritime nations to have coast guards that are able to protect their national interests. Nowadays, many countries of the world have coast guards under various names but performing similar functions of maritime law enforcement. The operations and equipment of modern coast guards also have become more and more sophisticated.

In the case of Malaysia, the MMEA, the Malaysian coast guard, is still struggling to achieve its primary objective of becoming a single maritime law enforcement agency with various maritime law enforcement functions under one roof. The main problem seems to be a veiled competition between the MMEA and other law enforcement bodies which also have powers in the maritime territories under other federal laws. Taking lessons from the successful coast guards of the world, the MMEA Act should be amended to clearly empower the MMEA with maritime law enforcement in the Malaysian maritime zones. The wholehearted support of the Government is also required and the MMEA should be placed under the Ministry of Defence rather than under the Prime Minister's Department. 